\title{
Ion content of polygonal wedge ice on Bolshoi Lyakhov: a source of palaeoenvironmental information
}

\author{
Oksana S. Savoskul \\ Institute of Geography, Russian Academy of Sciences, Staromonetny 29, Moscow 109017, Russia
}

\begin{abstract}
Bolshoi Lyakhov is one of the group of the New Siberian Islands in the Laptev Sea. The permafrost of the island is of an extremely low temperature regime, polygonal wedge ice being the most specific feature. The geomorphological level considered is a so-called edoma, presumably of late-Quaternary origin; polygonal ice wedges are more than $10 \mathrm{~m}$ wide and up to $25 \mathrm{~m}$ deep on this level, and about $1 \mathrm{~m} \times 1.5 \mathrm{~m}$ on the peat bogs of Holocene age. Sixty-six samples of underground ice were taken on both surfaces. The macro-ion content was analyzed, i.e. $\mathrm{Ca}, \mathrm{Mg}, \mathrm{Na}, \mathrm{K}$, $\mathrm{HCO}_{3}, \mathrm{Cl}, \mathrm{SO}_{4}$. A significant difference in ion content was found between the older and the younger ice. The late-Quaternary wedge ice is characterized by the predominance of $\mathrm{Ca}$ and $\mathrm{HCO}_{3}$, while the Holocene ice contains considerably higher proportions of $\mathrm{Na}$ and $\mathrm{Cl}$. This may be attributed to different environmental conditions during wedge-ice growth: more continental in the late Quaternary and more maritime in the Holocene.
\end{abstract}

\section{INTRODUCTION}

Polygonal wedge ice is the most specific feature of the permafrost of Bolshoi Lyakhov, New Siberian Islands, Russia. Only a few studies have been done in this vicinity on the chemistry of this type of underground ice (Volkova and Romanovskiy, 1974; Korzun, 1985). However, as was shown for western Siberia, the chemical content of underground ice could serve as an important source of palaeoenvironmental information when other data are not available (Danilov and others, 1980). The present paper considers the ion content of wedge ice of the late Quaternary and of the Holocene according to analyses of their macro-ion content, i.e. $\mathrm{Ca}, \mathrm{Mg}, \mathrm{Na}, \mathrm{K}, \mathrm{HCO}_{3}, \mathrm{Cl}$, $\mathrm{SO}_{4}$.

\section{STUDY AREA}

Bolshoi Lyakhov is the most southerly of the New Siberian Islands in the Laptev Sea (Fig. 1). No detailed data exist on the cryolithological features here. On the geological evidence, the permafrost of Bolshoi Lyakhov is very similar to that of the Jana-Kolyma lowland. The latter is of an extremely low temperature regime, the mean annual temperature at the bottom of the active layer being estimated as below $-10^{\circ} \mathrm{C}$ (Nekrasov, 1986). The Quaternary deposit of the Jana-Kolyma lowland, the so-called edoma complex, lying on Neogene marine strata, is a loose silt of loessial type with abundant plant remnants. Radiocarbon data indicate the late-Quaternary age (50000-11000 BP) of the edoma complex (Kaplina and others, 1980). Apart from the massive and segregation underground ice, this deposit contains polygonal wedge ice, with wedges $30-40 \mathrm{~m}$ deep. In some locations ice wedges up to $50-60 \mathrm{~m}$ deep have been described (Popov and others, 1985). Such extreme dimensions and other features of the ice wedges are explained by the hypothesis of syngenetic growth of ice wedges, i.e. an assumption of cryogenesis under conditions of continuous accumulation of the containing silt sediments, which are believed to be of alluvial origin

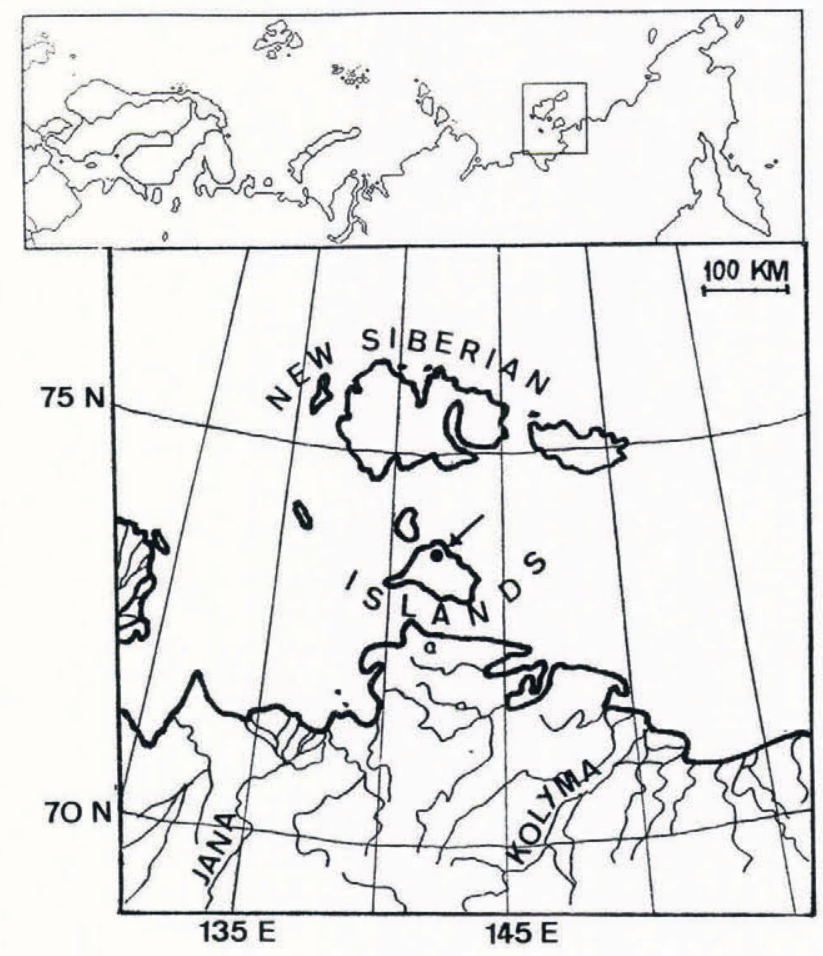

Fig. 1. Location of studied area. 
(Popov and others, 1985). However, there are other conceptions of the origin of these sediments, in particular that the edoma complex was deposited by wind (Tomirdiaro and Chernenkiy, 1984). According to another hypothesis, in the late Quaternary an Arcticshelf glacial sheet covered this territory (Grosval'd, 1989).

The Holocene permafrost structures occur mostly on the river banks, where they take the form of syngenetic ice wedges 1-2 $\mathrm{m}$ deep (Popov and others, 1985). During the Holocene Optimum the edoma surfaces were eroded by thermokarst processes, which led to the widespread development of peat bogs in the thermokarst depressions (Kaplina and Gitterman, 1983). In the late Holocene, when climate turned colder, a period of ice-wedge formation occurred on the peat bogs. Thus, on the edoma surface, apart from gigantic ice wedges of lateQuaternary age, Holocene ice wedges of smaller dimensions occur.

\section{STUDY SITES}

The study sites are located in the northern part of Bolshoi Lyakhov $\left(74^{\circ} \mathrm{N}, 142^{\circ} \mathrm{E}\right.$; Fig. 1). Based on geological drilling, the thickness of the late-Quaternary deposits at this location is $20-30 \mathrm{~m}$ (personal communication from P.S. Davidov, 1989). It is of the same pattern as the edoma complex of the Jana-Kolyma lowland, i.e. a lightbrown silt stratum with abundant plant remnants, mostly grass and herb roots in situ and thin peat layers from several millimetres to $1-2 \mathrm{~cm}$ thick. The content of massive and segregation ice in the deposit is very high, up to $30-40 \%$. The ice wedges are $5-10 \mathrm{~m}$ wide and up to 25-30 $\mathrm{m}$ deep. The length of polygons varies from 10 to $20 \mathrm{~m}$. The late-Quaternary deposits lie on gravel-sand marine deposits of Neogene age with massive underground ice and numerous ice lenses. The scattered Holocene deposits take the form of a peat stratum up to $1-1.5 \mathrm{~m}$ deep with ice wedges up to $1 \mathrm{~m}$ wide. The polygons are seldom longer than $3-5 \mathrm{~m}$.

The wedge ice was sampled in 11 outcrops (Fig. 2),

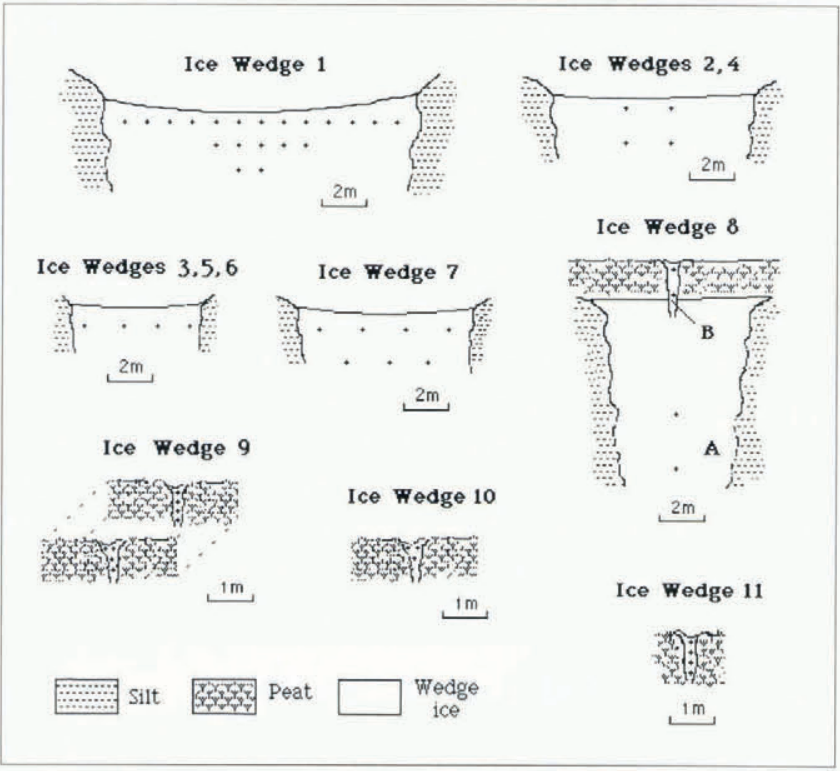

Fig. 2. Sketch of sampling points within the ice wedges. which are located along a strip $5 \mathrm{~km}$ long, stretching in an east-west direction, about $7 \mathrm{~km}$ from the north coast of the island. Since absolute dating was not feasible, the ice age was estimated according to geomorphic evidence and icewedge dimensions. Later on we will refer to the large ice wedges of the edoma complex as late-Quaternary ice (following Popov and others (1985); an assumption of the same age for this ice and the containing deposit was adopted) and to small narrow wedges as Holocene ice. The wedge ice is of very specific texture. Mostly it is unclear due to the high content of mineral particles and air pores. The texture is characterized by numerous subparallel vertical layers, which often cross each other. However, some relatively clear zones occur within the wedges. These are most specific to the Holocene ice. In ice wedges 1-7 the late-Quaternary ice is exposed. No. 8 is a complicated ice wedge: the narrow upper part $(8 \mathrm{~B})$ apparently grew after the formation of the wide lower part $(8 \mathrm{~A})$. Thus the upper two samples are likely to be of Holocene age and the lower two of late-Quaternary age. Ice wedges 9-11 are of Holocene age. The locations of sampling points within the ice wedges are shown in Figure 2.

\section{METHODS}

The samples were taken using axe and knife. Apart from the underground ice, snow and rain-water were sampled in the vicinity of the study sites, using plastic sheets and tools. The melted water was filtered and stored in $200 \mathrm{ml}$ plastic bottles. The analyses were carried out in the chemical laboratory at the Geographical Department of Moscow State University. The concentrations of $\mathrm{Ca}, \mathrm{Mg}, \mathrm{Na}$ and $\mathrm{K}$ were measured using an atom-adsorption spectrometer with an accuracy of $0.01 \mathrm{mgl}^{-1}$. $\mathrm{HCO}_{3}$ concentration was estimated by acid-alkaline titration using $0.01 \mathcal{N}$ solution of $\mathrm{HCl}$ with an accuracy of $0.05 \mathrm{mg} \mathrm{l}^{-1}$; $\mathrm{Cl}$ concentration by titration using $0.02 \mathrm{~N}$ solution of $\mathrm{AgNO}_{3}$ with an accuracy of $0.01 \mathrm{mgl}^{-1}$; and concentration of $\mathrm{SO}_{4}$ in solution of $\mathrm{BaCl}$ by spectrophotometer with an accuracy of $0.01 \mathrm{mgl}^{-1}$.

Concentrations of the ions, the $\mathrm{Cl} / \mathrm{Na}$ index and the mineralization averaged for each ice wedge and the corresponding standard deviations are presented in Table 1. The concentrations are expressed for each ion as a percentage calculated from concentrations expressed in milliequivalent separately for cations and anions assuming that the sum of macro-ions is $100 \%$ in each case. Mineralization is computed as the sum of macro-ion concentrations and expressed in $\mathrm{mg} \mathrm{l}^{-1}$. In order to get easily comparable data the mean values of ion concentrations, the $\mathrm{Cl} / \mathrm{Na}$ index and mineralization with standard deviations were computed separately for late-Quaternary ice, Holocene ice and samples of atmospheric water (Table 2).

\section{RESULTS}

Tables 1 and 2 and Figure 3 show that the lateQuaternary and Holocene ice differ considerably in values of mineralization. While the mineralization of the 


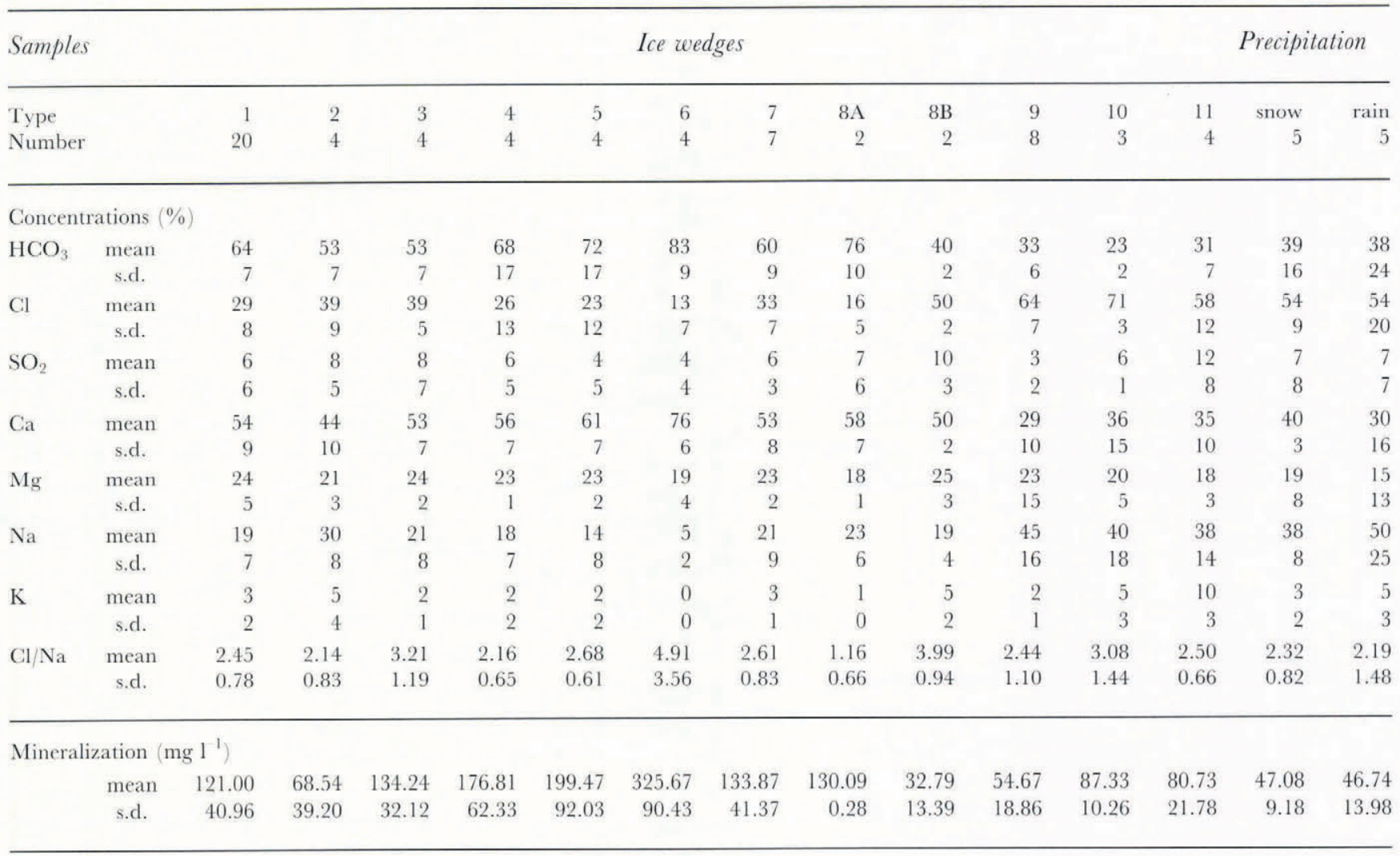

Holocene ice is very similar to the mineralization of present precipitation, that of late-Quaternary ice is approximately twice as great. The standard deviation of late-Quaternary ice indicates very high variability of the

Table 2. Averaged ion content of wedge ice and precipitation

\begin{tabular}{|c|c|c|c|c|}
\hline & & $\begin{array}{c}\text { Late Quater-nary } \\
\text { ice }\end{array}$ & $\begin{array}{l}\text { Holocene } \\
\text { ice }\end{array}$ & Precipitation \\
\hline \multicolumn{5}{|c|}{ Concentrations ( $\%)$} \\
\hline $\mathrm{HCO}_{3}$ & $\begin{array}{l}\text { mean } \\
\text { s.d. }\end{array}$ & $\begin{array}{l}65 \\
12\end{array}$ & $\begin{array}{r}31 \\
7\end{array}$ & $\begin{array}{l}39 \\
19\end{array}$ \\
\hline $\mathrm{Cl}$ & $\begin{array}{l}\text { mean } \\
\text { s.d. }\end{array}$ & $\begin{array}{l}29 \\
10\end{array}$ & $\begin{array}{r}62 \\
9\end{array}$ & $\begin{array}{l}54 \\
15\end{array}$ \\
\hline $\mathrm{SO}_{2}$ & $\begin{array}{l}\text { mean } \\
\text { s.d. }\end{array}$ & $\begin{array}{l}6 \\
5\end{array}$ & $\begin{array}{l}7 \\
6\end{array}$ & $\begin{array}{l}7 \\
7\end{array}$ \\
\hline $\mathrm{Ca}$ & $\begin{array}{l}\text { mean } \\
\text { s.d. }\end{array}$ & $\begin{array}{l}56 \\
10\end{array}$ & $\begin{array}{l}34 \\
11\end{array}$ & $\begin{array}{l}35 \\
12\end{array}$ \\
\hline $\mathrm{Mg}$ & $\begin{array}{l}\text { mean } \\
\text { s.d. }\end{array}$ & $\begin{array}{r}23 \\
4\end{array}$ & $\begin{array}{l}21 \\
10\end{array}$ & $\begin{array}{l}17 \\
10\end{array}$ \\
\hline $\mathrm{Na}$ & $\begin{array}{c}\text { mean } \\
\text { s.d. }\end{array}$ & $\begin{array}{r}19 \\
9\end{array}$ & $\begin{array}{l}39 \\
16\end{array}$ & $\begin{array}{l}44 \\
19\end{array}$ \\
\hline K & $\begin{array}{l}\text { mean } \\
\text { s.d. }\end{array}$ & $\begin{array}{l}3 \\
2\end{array}$ & $\begin{array}{l}5 \\
3\end{array}$ & $\begin{array}{l}4 \\
2\end{array}$ \\
\hline $\mathrm{Cl} / \mathrm{Na}$ & $\begin{array}{c}\text { mean } \\
\text { s.d. }\end{array}$ & $\begin{array}{l}2.72 \\
1.38\end{array}$ & $\begin{array}{l}2.58 \\
1.03\end{array}$ & $\begin{array}{l}2.25 \\
1.13\end{array}$ \\
\hline \multicolumn{5}{|c|}{ Mineralization $\left(\mathrm{mg} \mathrm{l}^{-1}\right)$} \\
\hline & $\begin{array}{c}\text { mean } \\
\text { s.d. }\end{array}$ & $\begin{array}{r}147.68 \\
78.30\end{array}$ & $\begin{array}{l}63.99 \\
24.62\end{array}$ & $\begin{array}{l}46.91 \\
11.15\end{array}$ \\
\hline
\end{tabular}

values of mineralization. However, mineralization of a few late-Quaternary samples is close to that of present precipitation.

The late-Quaternary ice is characterized by the predominance of $\mathrm{Ca}$ and $\mathrm{HCO}_{3}$, while the Holocene ice contains higher proportions of $\mathrm{Na}+\mathrm{K}$ and $\mathrm{Cl}$, the most variable in both cases being the concentrations of $\mathrm{SO}_{4}$ and $\mathrm{Mg}$. The ion content of the Holocene ice is very similar to that of present precipitation, where concentrations of $\mathrm{Na}$ and $\mathrm{Cl}$ are also much higher than in the lateQuaternary ice. An interesting point is that the proportions of $\mathrm{Ca}$ and $\mathrm{HCO}_{3}$ in late-Quaternary ice samples with low mineralization are also high. The variations of $\mathrm{SO}_{4}$ and $\mathrm{Mg}$ concentrations are of an uncertain pattern.

The $\mathrm{Cl} / \mathrm{Na}$ index is very variable, so it is not clear whether the differences between various types of samples should be attributed to genetical reasons or statistical variations.

The wedge ice is found to be chemically inhomogeneous in both the vertical and horizontal directions. However, no certain trend could be recognised in the variations of the ion content throughout the width of a wedge, as is clear from the comparison of 20 samples from ice wedge No. 1. Apparently there is a tendency for an increase of mineralization with depth in ice wedge No. 8, which could be explained by the complicated structure of the wedge, which contains ice of two different ages.

\section{DISGUSSION AND GONGLUSIONS}

The predominance of $\mathrm{Ca}$ and $\mathrm{HCO}_{3}$ in late-Quaternary wedge ice was reported from the Lena river, Jana lowland 

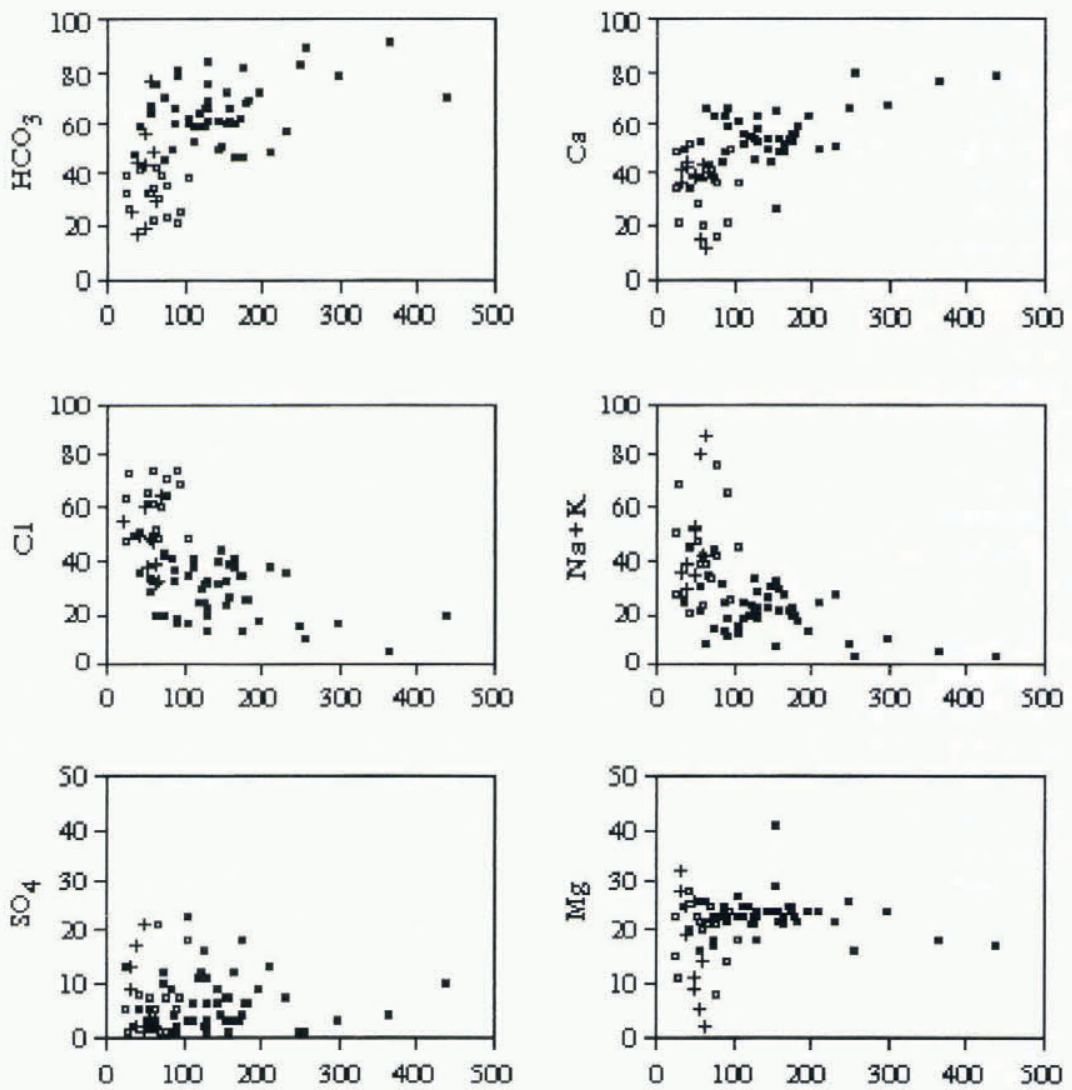

Fig. 3. Relations between the mineralization of the ice-wedge samples and the concentration of ions: xaxis, mineralization $\left(m g l^{l}\right)$; yaxis, concentrations $(\%) ; \mathbf{\square}$, Quaternary ice; $\square$, Holocene ice; +, precipitation.

(Volkova and Romanovskiy, 1974) and Yenisei river terraces (Danilov and others, 1980). Higher content of Cl and $\mathrm{Na}$ and lower concentrations of $\mathrm{Ca}$ and $\mathrm{HCO}_{3}$ in the Holocene wedge ice were reported from the Kolyma lowland Korzun, 1985) and the Arctic zone of western Siberia (Vasilchuk and Trofimov, 1984). Volkova and Romanovskiy (1974) explain the differences between the ion content of late-Quaternary and Holocene ice by variations in the chemical content of precipitation. However, interpretation of these differences should be very careful, since the ion content of atmospheric precipitation and of underground ice are not as closely related as in the case of glacier ice.

Figure 3 shows the relations between the values of mineralization and concentrations of the macro-ions. As is clear from the graphs, with increasing mineralization the proportions of $\mathrm{Ca}$ and $\mathrm{HCO}_{3}$ increase in late-Quaternary ice and those of $\mathrm{Na}$ and $\mathrm{Cl}$ decrease. Thus higher concentrations of $\mathrm{Ca}$ and $\mathrm{HCO}_{3}$ in late-Quaternary ice having high mineralization could be ascribed to later alteration, for instance by the ion input from minerals. Nevertheless, it is important to stress that even samples with mineralization lower than $60 \mathrm{mg} \mathrm{l}^{-1}$, very close to the mineralization of present precipitation and consequently insignificantly altered by ion exchange with minerals, also contain high proportions of $\mathrm{Ca}$ and $\mathrm{HCO}_{3}$. This could mean that the late-Quaternary ice was initially formed from water of different chemical content to the Holocene ice. Presumably this ice-forming water was of atmospheric origin. The similarity of ion concentrations in present precipitation and Holocene ice, as well as low mineralization of the latest ice, show that the wedge ice could be used as a rough indicator of chemical content of precipitation. The samples with low mineralization from the late-Quaternary ice are likely to be acceptable for this purpose as well.

Thus an increase of $\mathrm{Ca}+\mathrm{HCO}_{3}$ and consequently a decrease of $\mathrm{Na}+\mathrm{Cl}$ in the precipitation during the late Quaternary as compared to the Holocene is likely. This may be attributed to different environmental conditions during wedge-ice growth: more continental in the lateQuaternary and more maritime in the Holocene. Other indicators of the palaeoenvironmental conditions in the region allow such a conclusion. For instance palynological data from the stratotypical sections in the JanaKolyma lowland give evidence of an extremely cold and dry climate during the major part of the late Quaternary between 50000 and $11000 \mathrm{BP}$ which was replaced by a warmer, more humid climate in the Holocene (Kaplina and others, 1980; Kaplina and Gitterman, 1983; Tomirdiaro and Chernenkiy, 1984; Rybakova, 1990).

The similarity of the chemical content of lateQuaternary wedge ice in the studied sites and in the adjacent continental areas (Volkova and Romanovskiy, 1974) suggests a similarity in the palaeoenvironmental conditions of ice growth. It is likely that Bolshoi Lyakhov was part of the Indigirka delta during the late Quaternary and that the silt stratum containing the wedge ice was formed by accumulation of alluvial deposits. The existence of an ice-sheet cover on this territory, as stated by Grosval'd (1988), is therefore very unlikely. Perhaps considerably smaller glaciers covered northern islands of the New Siberian group at that time. 


\section{REFERENCES}

Danilov, I. D., V.I. Solomatin and N. A. Shmideberg. 1980. Khimicheskiy sostav podzemnykh l'dov kak pokazatel' uslovii ikh formirovaniya i genezisa vmeshchaiushchikh porod [Chemical composition of ground ice as an indication of ice formation conditions and origin of the enclosing rocks]. In Popov, A. I. and V.T. Trofimov, eds. Prirodnyye usloviza Zapadnoy Sibiri. Vypusk 7 Environment in western Siberia. Issue 7]. Moscow, Izdatel'stvo Moskovskogo Universiteta, 119-126.

Grosval'd, M. G. 1988. Priznaki pokrovnogo oledeneniya Novosibirskikh Ostrovov i okruzhayushchego shel'fa [Evidence of ice-sheet glaciation of Novosibirskiye Ostrova and surrounding shelf]. Dokl. Akad. Nauk SSSR, 302 3), 654 659.

Kaplina, T.N. and R. Ye. Giterman. 1983. Molotkovskiy Kamen'opornyi razrez otlozheniy pozdnego pleystotsena Kolymskoy nizmennosti [Molotkovskiy Kamen' reference section of Late Pleistocene deposits in the Kolyma lowland.] Izv. Akad. Nauk SSSR, Ser. Geol., 6, 79-83.

Kaplina, T. N., G. N. Shilova and L. G. Pirumova. 1980. Shamanovskiy opornyi razrez pozdnepleystotsenovykh i golotsenovykh otlozheniy Indigirki [Shamanovskiy reference section of Late Pleistocene and Holocene deposits of the Indigirka area]. Izv. Akad. Nauk SSSR, Ser. Geol., 9, 7481

Korzun, A.V. 1985. Geokhimicheskie protsessy v lednikovykh i podsemnykh l'dakh severa Eurasii [The geochemical processes in glacial and underground ice in northern Eurasia]. Ph.D. thesis, Moscow State University.)
Nekrasov, I. A. 1986. Vechnaya merslota Yakutii [Permafrost of Yakutia]. Yakutsk, Nauka, 37.

Popov, A. I., G.E. Rozenbaum and N.V. Tumel'. 1985. Kriolitologiya Cryolithology . Moskow, etc., Izdatel'stvo Moskovskogo Universiteta.

Rybakova, N.O. 1990. [Changes in the vegetation cover and climate in the Kolyma lowlands in Late-Quaternary time]. Polar Geogr. Geol., 14(*), 279-286. Translated from Skabichevskaya, N. A., ed. Pleystotsen Sibiri $i$ stratigrafiya $i$ mezhregional'nyye korrelyatsii The Pleistocene of Siberia: stratigraphic and interregional correlations]. Novosibirsk, Nauka, 1989, 137-142. (Tr. Inst. Geol. Geophiz. 657.)

Tomirdiaro, S. V. and B. I. Chernenkiy. 1984. Osobennosti izucheniya pleystotsenovykh otlozheniy Yedomnoy serii Severo-Vostoka SSSR [Details of the Pleistocene sediments of the Edoma complex in northeastern USSR]. In Bespalyy, V.G., ed. Pleystotsenovyye oledeneniya Vostoka Azii [The Pleistocene glaciation of eastern Asia]. Magadan, Severo-Vostochnyy Kompleksnyy Nauchno - Issledovatel'skiy Institut, 159-173.

Vasil'chuk, Yu. K. and V. T. Trofimov, 1984. K voprosu o mineraliyatsii poligonal'nozhilnikh l'dov [On the mineralization of polygonal wedge ice]. Izv. Akad. Nauk SSSR, Ser. Geol., 8, 129-134.

Volkova, V. P. and N. N. Romanovskiy. 1974. O khimicheskom sostave podsemnykh l'dov v chetvertichnykh otlozheniiakh iuzhnoi chasti Iano-Indigirskoy nizmennosti [Chemical composition of ground ice in the Quaternary deposits in the southern part of the Iana-Indigirka lowland]. In Popov, A. I., ed. Problemy kriolitologii. Vypusk 4 [Problems of cryolithology. Issue 47. Moscow, Izdatel'stvo Moskovskogo Universiteta, 112-135. 